\title{
A literature review on "Prevalence and causes of common musculoskeletal injuries in badminton players"
}

\author{
Pinky Dutta*1 and Kiran Kumar SV²
}

\author{
${ }^{1}$ Research Scholar, Department of Physiotherapy, Garden City University \\ $16^{\text {th }}$ K.M old Madras Road, Virgo nagar Post, Bangalore-560049 \\ ${ }^{2}$ Assistant Professor, Department of Physiotherapy, Garden City University \\ $16^{\text {th }}$ K.M old Madras road, Virgo nagar Post, Bangalore-560049 \\ *Corresponding Author: Pinky Dutta; dutta.pinky@gmail.com
}

\section{ABSTRACT \\ Background}

The most injuries of badminton players involve a critical association between the movement tasks and training programs strategies. This review highlights on the common musculoskeletal injuries experienced by badminton players. The large majority of injuries, when recognized early on, can be prevented effectively with minor adjustments in the training programs, rehabilitation of essential muscles and flexibility.

\section{Objectives}

1. To determine the common musculoskeletal injuries experienced by badminton players

2. To determine some probable cause of musculoskeletal sports injuries experienced by badminton players.

\section{Methodology}

A review was conducted on articles published between the year 2007 to 2018 to draw a conclusion on the prevalence and prevention of the common musculoskeletal injuries in badminton players. 20 studies including research articles was reviewed. The studies were critically appraised and cross references were checked.

\section{Results and Conclusion}

According to the results of this research the incidence of injury in the lower and upper extremities are relatively high in badminton players. The implementation of custom fit physical fitness training programme, physiotherapy, continual medical supervision, considering scientific and practical principles to all level of athletes can be effective in the prevention of sports injuries.

\section{Discussion}

Further studies to be conducted in a broader perspective way. Also, physical fitness training programme should be formulated based on the demand of the sport and the athlete.

Keywords: badminton; musculoskeletal injuries; physical fitness; sports injury

\section{INTRODUCTION}

Badminton is a popular sport that is enjoyed by both sexes and people of all ages around the world. Unlike recreational badminton, competitive badminton places a great deal of load on the player due to vigorous upper arm, trunk, and leg movements. Consequent to the vigorous movements and exercise load, many players suffer trauma and injury. ${ }^{1}$ The Badminton World Federation (BWF) estimated that about 150 million people play the game worldwide and that more than 2,000 players participate in international competitions. It is played by people of all ages and at all levels. Badminton is a non -contact racquet sport requiring jumps, lunges, quick changes in direction and rapid arm movements from a wide variety of postural positions. ${ }^{2}$ A competitive badminton involves applying a high concentration of running, jumping, spinning, stretching, and walking back. Advanced levels of sport require high speed, coordination, quick reactions, agility and a relatively good physical condition. During such movements, the body may be susceptible to various injuries. In badminton, injuries often occur with high intensity and low intensity traumas. Therefore, it is common for badminton players to get different injuries during the game.3,4

An injury is defined as an episode of pain, swelling, stiffness or numbness during playing badminton or after the game. Badminton injuries as a whole are predominantly sprains and strains, and overuse in nature. The injuries in badminton can be recognized on basis of type of injuries, severity and body part. ${ }^{3}$ It is necessary to understand the injury prevalence, so as to predict risk factors and to set up preventive measures to prevent injuries. 
Also, to make awareness for coaches to develop a better plan for training thereby reduce risk of injury and improve training quality. ${ }^{4}$ The study is conducted to assess the prevalence and some probable causes of sport injuries in Badminton Players.

\section{METHODOLOGY}

Extensive review of research articles from various academic research repositories like MEDLINE, SCIENCE DIRECT, PUBMED CENTRAL, SCOPUS, COCHRAINE LIBRARY, Index to Nursing and Allied Health and Science Citation from 2007 to 2018 was conducted for this review. The medical subject headings 'musculoskeletal injury', 'prevalence,' 'badminton', 'sports injury' were used. The search was limited to studies printed in English and to the study of badminton players only. A total number of 20 research articles were reviewed. Cross references of each study was extensively researched and the studies were appraised critically.

The following table briefs few researches that were taken into consideration.

\begin{tabular}{|c|c|c|c|}
\hline $\begin{array}{r}\text { Sl } \\
\text { no. }\end{array}$ & Title & Journal & Result \& Conclusion \\
\hline 1. & $\begin{array}{l}\text { Epidemiology of injuries } \\
\text { in Hong Kong elite } \\
\text { badminton athletes. }{ }^{5}\end{array}$ & $\begin{array}{l}\text { Research in Sports } \\
\text { Medicine, } \\
15(2), \text { pp.133-146, } \\
\text { year } 2007\end{array}$ & $\begin{array}{l}\text { Elite senior athletes had a higher incidence rate of } \\
\text { recurrent injuries, while elite junior and potential athletes } \\
\text { had higher incidence rate of new injuries. Most new } \\
\text { injuries were strain ( } 80 \text { injuries), and the most frequently } \\
\text { injured body sites were the back ( } 17 \text { injuries), the shoulder } \\
\text { ( } 15 \text { injuries), the thigh ( } 15 \text { injuries) and the knee ( } 15 \\
\text { injuries). One-sided exact test showed that a previous } \\
\text { injury experience significantly associated with the } \\
\text { occurrence of new injury. }\end{array}$ \\
\hline 2. & $\begin{array}{l}\text { The Prevalence and Causes } \\
\text { of Sport Injuries in Well- } \\
\text { Trained Badminton Players } \\
\text { of Iran. }{ }^{4}\end{array}$ & $\begin{array}{l}\text { International Journal } \\
\text { of Basic Sciences \& } \\
\text { Applied Research. } \\
\text { Vol., 3(1), 40-44, } 2014\end{array}$ & $\begin{array}{l}\text { the incidence of injury in the lower and upper extremities } \\
\text { are relatively high in Iranian well trained badminton } \\
\text { players. It seems that the use of massage, physiotherapy, } \\
\text { continual medical supervision, considering scientific and } \\
\text { practical principles, promotion of physical fitness level of } \\
\text { athletes can be effective in the prevention of sports injuries. }\end{array}$ \\
\hline 3. & $\begin{array}{l}\text { Risk Factors for Shoulder } \\
\text { Pain in Japanese } \\
\text { Badminton Players: } \\
\text { A Quantitative-Research } \\
\text { Survey. }{ }^{6}\end{array}$ & $\begin{array}{l}\text { Journal of Sports } \\
\text { Science } \\
(6), 84-93,2018\end{array}$ & $\begin{array}{l}\text { Analysis of patients excluding those with a history of } \\
\text { shoulder pain indicated that undergoing care, being of } \\
\text { university age, having a long history of competing, and } \\
\text { short cool-down times were associated with recurrent } \\
\text { pain. However, results were different for each age group. } \\
\text { The fact that half the Japanese middle school, high school, } \\
\text { and university badminton players had a history of } \\
\text { shoulder pain suggests that they will experience recurrent } \\
\text { shoulder pain. The results also suggest that different } \\
\text { factors are important in each age group. }\end{array}$ \\
\hline 4. & $\begin{array}{l}\text { Musculoskeletal injuries } \\
\text { among Malaysian } \\
\text { badminton players }^{7}\end{array}$ & $\begin{array}{l}\text { Singapore Med J; } \\
50(11): 1095,2009\end{array}$ & $\begin{array}{l}\text { The majority ofthe injuries sustained by badminton } \\
\text { players in this study were due to overuse, primarily in the } \\
\text { knee. The majority of the injuries were diagnosed in } \\
\text { younger players and occurred during training/practice } \\
\text { sessions. There was no difference in terms of incidence and } \\
\text { types of injuries between the genders. }\end{array}$ \\
\hline 5. & $\begin{array}{l}\text { Common Injuries in Racket } \\
\text { Sports: A Mini Review. }{ }^{8}\end{array}$ & $\begin{array}{l}\text { Orthopedic surgery } \\
\text { and Orthopedic care } \\
\text { International } \\
\text { journal. } \\
\text { ISSN } 2578-0069 \\
2018\end{array}$ & $\begin{array}{l}\text { The review highlights on the common injuries and anatomical } \\
\text { regions of tennis, badminton and squash players injuries. The } \\
\text { large majority of injuries, when recognized early on, can be } \\
\text { prevented effectively with minor adjustments in the training } \\
\text { programs, rehabilitation of essential muscles and flexibility } \\
\text { imbalances, and awareness to proper footwear. }\end{array}$ \\
\hline 6. & $\begin{array}{l}\text { Musculoskeletal problems } \\
\text { in badminton players } \\
\text { under } 17 .{ }^{9}\end{array}$ & $\begin{array}{l}\text { International Journal } \\
\text { Of Physical Education } \\
\text { Sports and Health; } \\
5(5): 67-70,2018\end{array}$ & $\begin{array}{l}\text { This study concludes that majority of the players had pain } \\
\text { in Wrist followed by Neck and Shoulder. Other type of } \\
\text { injury which includes Muscle catch and Muscle cramp was } \\
\text { the most common type of injury. This was followed by } \\
\text { Strain/ Sprain. Strain was more common in Males and } \\
\text { Sprain in Females. }\end{array}$ \\
\hline 7. & $\begin{array}{l}\text { The prevalence and } \\
\text { causes of sport injuries in } \\
\text { well-trained badminton } \\
\text { players of Iran. }{ }^{10}\end{array}$ & $\begin{array}{l}\text { International Journal } \\
\text { of Basic Sciences and } \\
\text { Applied Research } \\
\text { Vol.3 No.1 pp.40-44, } \\
2014\end{array}$ & $\begin{array}{l}\text { According to the results of this research the incidence of injury } \\
\text { in the lower and upper extremities are relatively high in } \\
\text { Iranian well trained badminton players. It seems that the use } \\
\text { of massage, physiotherapy, continual medical supervision, } \\
\text { considering scientific and practical principles, promotion of } \\
\text { physical fitness level of athletes can be effective in the } \\
\text { prevention of sports injuries. }\end{array}$ \\
\hline
\end{tabular}




\begin{tabular}{|c|l|l|l|}
\hline 8. & $\begin{array}{l}\text { Badminton injuries in } \\
\text { youth competitive } \\
\text { players. }{ }^{11}\end{array}$ & $\begin{array}{l}\text { The Journal of sports } \\
\text { medicine and } \\
\text { physical } \\
\text { fitness 53(1):65-70 } \\
\text { February 2013 }\end{array}$ & $\begin{array}{l}\text { Badminton injuries mostly involved the lower limb and } \\
\text { almost all overuse injuries occurred in the lower limb. } \\
\text { However, badminton injuries as a whole were } \\
\text { predominantly sprains and strains, and not overuse in } \\
\text { nature as widely believed. }\end{array}$ \\
\hline 9. & $\begin{array}{l}\text { A Survey on Common } \\
\text { Injuries in Recreational } \\
\text { Badminton Players. 12 }\end{array}$ & $\begin{array}{l}\text { Malaysian } \\
\text { Orthopedic Journal, } \\
\text { vol 3 No 2, 2009 }\end{array}$ & $\begin{array}{l}\text { The result suggested that the most common injury sustained } \\
\text { by recreational badminton players was pain and stiffness at } \\
\text { the shoulder joint. None of the injuries sustained by the } \\
\text { players were serious enough to warrant any form of surgical } \\
\text { intervention. We conclude that badminton is a sport of } \\
\text { relatively low risk and that the majority of related injuries } \\
\text { were chronic overuse injuries. }\end{array}$ \\
\hline 10. & $\begin{array}{l}\text { Prevalence of Achilles } \\
\text { Tendinopathy among } \\
\text { Recreational Badminton } \\
\text { Players. 13 }\end{array}$ & $\begin{array}{l}\text { International } \\
\text { Journalof } \\
\text { Pharmaceutical Bio } \\
\text { Science Volume } 9 \\
\text { Issue 1: 229-231, } \\
\text { Achilles tendinopathy in recreational badminton injuries }\end{array}$ & \\
\hline
\end{tabular}

\section{RESULTS AND CONCLUSION}

The current study was to determine the prevalence and causes of sports injuries among badminton players. It was indicated firstly that the relative incidence of sports injuries was significantly higher. ${ }^{4}$ Studies have revealed that in badminton sport injuries, a rate of 2.9 injuries per player occurs per 1000 hours of badminton playing. Injuries that related to this sport tend to be due to overuse and lack of physical fitness training as badminton is a non-contact sport. Badminton players requires explosive power for flicks of the wrist, jumps, lunges and rapid changes of direction. ${ }^{8}$

Wrist, Neck and Shoulder were the three most common areas of problem in badminton players. Wrist pain was the most common site of injury in them. This could be due to repeated flexion extension of wrist for playing different types shots. Majority of players with Wrist pain had associated Shoulder and Neck pain. Upper limb injuries were most likely to occur when the shoulder transform from the cocking phase to acceleration phase. It gives great stress to the shoulder as it transformed from external rotation to internal rotation rapidly. This explained why more than half of the Badminton players had upper limb pain. Some possible causes of shoulder injury including overtraining, inadequate skill level, wrong movement, competition, lack of warm up, stiff muscle, tired, lack of recovery and muscle imbalance. ${ }^{9}$ In the lower limb commonest type of injury were patellar tendinopathy, ankle sprain, muscle cramps and Achilles' tendinopathy. 7 This current study also demonstrated that the majority of injuries occurred in the younger age group. It was observed that higher incidence of injury is among players between 18 and 25 years of age.

The possible explanations for this observation could be the lack of experience among younger players and possibly, a more aggressive style of play. Another interesting finding was that most of the injuries were sustained during training or practice, rather than in competition. ${ }^{7}$

\section{DISCUSSION}

From the present study, we can conclude that there is a high prevalence of injury in badminton players both in the upper limb, spine and lower limb. The risk of injury can be because of inadequate physical fitness training and also improper technique of playing the sport. In order to prevent the injuries an updated physical fitness training protocol should be formulated taking into consideration of all the causes of injuries. An extensive literature review should be conducted to come to a conclusion. The literature reviewed here were less. Future studies are recommended to compare the prevalence and causes of musculoskeletal injuries with other sports.

\section{REFERENCES}

[1] Risk Factors for Shoulder Pain in Japanese Badminton Players: A Quantitative-Research Survey. Journal of Sports Science 6 (2018) 84-93 doi: 10.17265/2332-7839/2018.02.003

[2] Musculoskeletal injuries among Malaysian badminton players. Singapore Med J 2009; 50(11): 1095

[3] Musculoskeletal problems in badminton players under 17. International Journal of Physical Education, Sports and Health 2018; 5(5): 67-70

[4] The Prevalence and Causes of Sport Injuries in Well-Trained Badminton Players of Iran. International Journal of Basic Sciences \& Applied Research. Vol., 3 (1), 40-44, 4104

[5] Epidemiology of injuries in Hong Kong elite badminton athletes. Research in Sports Medicine, 15 (2), pp.133-146.

[6] Risk Factors for Shoulder Pain in Japanese Badminton Players: A Quantitative-Research Survey. Journal of Sports Science (6), 84-93, 2018

[7] Musculoskeletal injuries among Malaysian badminton players. Singapore Med J; 50(11) : 1095, 2009

[8] Common Injuries in Racket Sports: A Mini Review. Orthopedic surgery and Orthopedic care International journal. ISSN 2578-0069,2018

[9] Musculoskeletal problems in badminton players under 17. International Journal of Physical Education, Sports and Health; 5(5): 67-70, 2018 
[10] The prevalence and causes of sport injuries in well-trained badminton players of Iran. International Journal of Basic Sciences and Applied Research Vol.3 No.1 pp.40-44, 2014

[11] Badminton injuries in youth competitive players. The Journal of sports medicine and physical fitness 53(1):65-70, February 2013

[12] A Survey on Common Injuries in Recreational Badminton Players. Malaysian Orthopedic Journal, vol 3 No 2, 2009

[13] Prevalence of Achilles Tendinopathy among Recreational Badminton Players. International Journalof Pharmaceutical Bio Science, Volume 9 Issue 1:229-231, 2018 